\title{
Impact of rainfall spatial distribution on rainfall-runoff modelling efficiency and initial soil moisture conditions estimation
}

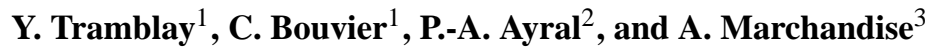 \\ ${ }^{1}$ Hydrosciences Montpellier, UMR 5569, CNRS-IRD-UM1-UM2, Université Montpellier 2, Maison des Sciences de l'Eau, \\ Place Eugène Bataillon, 34095 Montpellier Cedex 5, France \\ ${ }^{2}$ Ecole Des Mines d'Alès, 6 Avenue de Clavières, 30319 Alès Cedex, France \\ ${ }^{3}$ SCHAPI, 42 Avenue Gaspard Coriolis, 31057 Toulouse Cedex 1, France
}

Received: 2 October 2010 - Revised: 7 December 2010 - Accepted: 8 December 2010 - Published: 18 January 2011

\begin{abstract}
A good knowledge of rainfall is essential for hydrological operational purposes such as flood forecasting. The objective of this paper was to analyze, on a relatively large sample of flood events, how rainfall-runoff modeling using an event-based model can be sensitive to the use of spatial rainfall compared to mean areal rainfall over the watershed. This comparison was based not only on the model's efficiency in reproducing the flood events but also through the estimation of the initial conditions by the model, using different rainfall inputs. The initial conditions of soil moisture are indeed a key factor for flood modeling in the Mediterranean region. In order to provide a soil moisture index that could be related to the initial condition of the model, the soil moisture output of the Safran-Isba-Modcou (SIM) model developed by Mété-France was used. This study was done in the Gardon catchment $\left(545 \mathrm{~km}^{2}\right)$ in South France, using uniform or spatial rainfall data derived from rain gauge and radar for 16 flood events. The event-based model considered combines the SCS runoff production model and the Lag and Route routing model. Results show that spatial rainfall increases the efficiency of the model. The advantage of using spatial rainfall is marked for some of the largest flood events. In addition, the relationship between the model's initial condition and the external predictor of soil moisture provided by the SIM model is better when using spatial rainfall, in particular when using spatial radar data with $R^{2}$ values increasing from 0.61 to 0.72 .
\end{abstract}

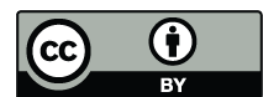

Correspondence to: Y. Tramblay

(ytramblay@gmail.com)

\section{Introduction}

Flash floods are a very destructive hazard in the Mediterranean region. They are caused by intense rainfall events inducing short flood rising times, usually several hours. For hydrological operational purposes such as flood forecasting, a good knowledge of rainfall is essential when dealing with flood events. Andréassian et al. (2001) or Wagener et al. (2007) have indicated how crucial it is to test the sensitivity of rainfall-runoff models to different rainfall inputs, in order to assess their sensitivity and robustness. The rainfall characteristics, in particular the spatial distribution of rainfall and its intensity are known to influence the modeling of flooding events (Andréassian et al., 2004; Saulnier and Le Lay, 2009). A large part of the rainfall-runoff modelling errors can be explained by the uncertainties on rainfall estimates (Moulin et al., 2009; Sangati and Borga, 2009). Arnaud et al. (2002) showed that using mean areal rainfall instead of spatially distributed rainfall tends to underestimate the volumes and the peak flows, when using the same calibration of the rainfall-runoff model. This underestimation increases according to the spatial coefficient of variation of the rainfall. However, the possibility to recalibrate the model in order to get equivalents results with uniform or spatial rainfall as model inputs has been little investigated up to now. This question was addressed in the present study using an event-based rainfall-runoff distributed model.

Event-based models are often preferred to continuous models for real time operational applications and forecasting in combination with radar spatial rainfall (Reed et al., 2007; Javelle et al., 2010), but their main limitation remains that the initial conditions need be set from additional external information (Berthet et al., 2009). The response of a catchment to a rainfall event is greatly influenced by the antecedent soil moisture conditions, which are crucial parameters for flood modeling (Norbiato et al., 2008; Brocca

Published by Copernicus Publications on behalf of the European Geosciences Union. 
et al., 2009a; Marchi et al., 2010). In recent studies, significant relationships have been established for small catchments between initial conditions of event-based SCS models (Mishra and Singh, 2003) and in situ soil moisture measurements (Huang et al., 2007; Brocca et al., 2009a, Tramblay et al., 2010). For larger catchments, an alternative to local monitoring could be to use soil moisture data retrieved from satellite products (Jacobs et al., 2003; Brocca et al., 2009b, 2010; Beck et al., 2010). Marchandise and Viel (2009) or Tramblay et al. (2010) reported satisfactory correlations between the soil moisture output of the SIM model developed by MétéoFrance (Habets et al., 2008) and the initial conditions of an event-based model, indicating its usefulness for flood modeling and forecasting. However, such correlations require a robust calibration of the initial condition of the model. A issue needing to be addressed is the test to find out how far spatial rainfall data could improve the robustness of the initial condition calibration and the quality of the correlations with external soil moisture indicators, which will be used for expanding the use of the model out of the calibration domain.

In the context of flash flood forecasting, recent studies have focused on using radar rainfall data to determine rainfall and discharge thresholds coupled with soil moisture, in particular for ungauged catchments (Norbiato et al., 2008; Montesarchio et al., 2009; Javelle et al., 2010). In addition to traditional rain gauge networks, radar-derived rainfall data are becoming more available for flood modeling, providing high temporal and spatial resolution estimates of rainfall (Delrieu et al., 2009; Sangati and Borga, 2009; Javelle et al., 2010). Nevertheless, the modeling efforts are often mitigated; the impact of the spatial distribution of rainfall on runoff estimation is complex and can be dependent on the nature of the rainfall, the nature of the catchment, and the spatial scale considered (Segond et al., 2007). Comparisons between studies concerning floods in several Mediterranean catchments would be valuable to evaluate the benefits of using a distributed hydrological model with different rainfall sources (Yates et al., 2000; Cole and Moore, 2008; Saulnier and Le Lay, 2009; Bonnifait et al., 2009). As indicated by Delrieu et al. (2009), re-analysis of gauges and radar rainfall data that has been collected in the past 30 years would be useful for research and engineering applications, such as the analysis of extremes or the forcing of distributed hydrological models.

The objective of this paper was to analyze how flood modeling with an event-based model can be sensitive to the use of spatially distributed rainfall compared to mean areal rainfall, uniform over the watershed. Two questions were addressed: what is the impact of taking into account the spatial variability of rainfall on (1) the model efficiency for the flood peak and volume simulations, (2) the relationship between the initial condition of the model and an external antecedent soil moisture predictor? This study was done in the Gardon catchment $\left(545 \mathrm{~km}^{2}\right)$ in South France using uniform or spatial rainfall derived from rain gauge and radar rainfall data.
The event-based model considered was the distributed SCSLR model, which combines the SCS runoff model and the Lag and Route routing model. First, the efficiency of the model was compared for the different types of rainfall inputs, allowing the model to be calibrated for each type of rainfall input. Second, the relationships between the calibrated initial condition of the event-based model and a soil moisture index were also compared for the different rainfall inputs.

\section{Rainfall-runoff model}

The hydrological model used here combines a GIS-based distributed version of the runoff model of the Soil Conservation Service (SCS) and a Lag and Route (LR) routing model. The SCS runoff model has been developed by the United States Department of Agriculture (see Mishra and Singh, 2003 for a review) and has been widely used for flood modeling, partly because it performs efficiently while using a reduced number of parameters. SCS is commonly interpreted as direct surface runoff but it can also describe soil saturation processes (Steenhuis et al., 1995). The lag and route routing model has also been widely used (Bentura and Michel, 1997). The model was implemented in the ATHYS modeling platform (http://www.athys-soft.org).

The distributed model lies on the following steps:

1. A digital elevation model (DEM) was used to define a regular grid of cells of $500 \times 500 \mathrm{~m}$ over the watershed.

2. The rainfall of each cell was interpolated using the Thiessen method.

3. The runoff from each cell was calculated using a SCS runoff model.

4. Each cell produced an elementary hydrograph at the outlet, using a lag and route routing model (Fig. 1).

5. The complete hydrograph of the flood was obtained after addition of the elementary hydrographs.

\subsection{Runoff model}

For each cell of the catchment, the effective precipitation $(\mathrm{mm})$ contributing to runoff at the time $t, P e(t)$, is derived from the instantaneous precipitation $P b(t)$, using a SCSbased relationship between the cumulative rainfall $P(t)$ at the time $t$ and a reservoir capacity $S$ (Gaume et al., 2004):

$P e(t)=P b(t)\left(\frac{P(t)-0.2 . S}{P(t)+0.8 . S}\right)\left(2-\frac{P(t)-0.2 . S}{P(t)+0.8 . S}\right)$

A reduction of the cumulative rainfall has been considered, in order to simulate the decrease of the runoff coefficient in case of intermittent rainfall (Bouvier et al., 2006). This reduction allows a better simulation of the flood events having more 


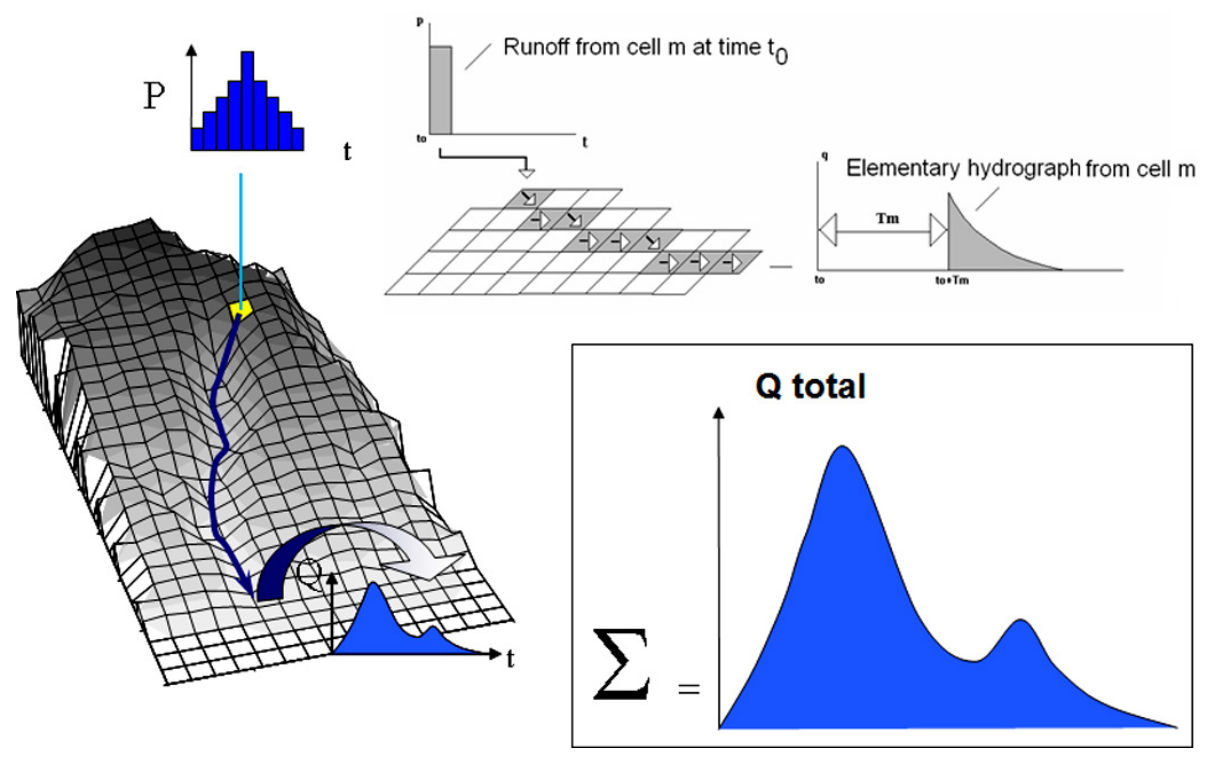

Fig. 1. Diagram of the lag and route routing model.

than one peak, and was applied as a linear function of the cumulative rainfall at time $t$, according to the coefficient $d s$ :

$\frac{d P(t)}{d t}=P b(t)-d s P(t)$

with $P(0)=0$ at the beginning of the event

Thus, the runoff model accounts for two parameter, $S$ and $d s$. $S$ is the maximal soil water retention and can be considered as the initial water deficit at the beginning of each event. Therefore the $S$ parameter is the initial condition of the event-based model (i.e. it depends on each event). In this application, the runoff parameter $S$ does not vary in space, but remains the same for all the cells. The $d s$ parameter can be considered as the drainage of the soil water and can be obtained from the recession curves of the observed flood hydrographs. If assuming that the retention curves are of exponential type, the $d s$ parameter can thus be derived from:

$Q(t)=Q\left(t_{0}\right) \exp \left(-d s\left(t-t_{0}\right)\right.$

The Eq. (3) is adjusted to the recession part of the observed flood hydrograph. In the present study, $d s$ is fixed to its median values obtained with all the events.

\subsection{Routing model}

The effective rainfall is then routed from the cell to the outlet of the catchment. For each cell $\mathrm{m}$, the model computes a propagation time at the outlet, $T_{\mathrm{m}}$ and a diffusion time $K_{\mathrm{m}}$ :

$T_{\mathrm{m}}=\frac{l_{\mathrm{m}}}{V_{0}}$

$K_{\mathrm{m}}=K_{0} T_{\mathrm{m}}$ where $l_{\mathrm{m}}$ is the length of the flow path from the cell $\mathrm{m}$ to the outlet, $V_{0}$ the speed of propagation $\left(\mathrm{m} \mathrm{s}^{-1}\right)$, and $K_{0}$ a coefficient without dimension. $V_{0}$ and $K_{0}$ are assumed here to be identical for each cell, and must be calibrated from rainfall and discharge data. In the present study, only $V_{0}$ is varying for each event and $K_{0}$ is set to a constant value. The flow paths from the cell to the outlet are derived from the DEM.

The elementary discharge $q(t)$ due to the effective rainfall $\mathrm{Pe}\left(t_{0}\right)$ of cell $\mathrm{m}$ at time $t_{0}$ is given by:

$$
\begin{array}{ll}
q(t)=0 & \text { if } t<t_{0}+T_{\mathrm{m}} \\
q(t)=\frac{P e\left(t_{0}\right)}{K_{\mathrm{m}}} \exp \left(-\frac{t-\left(t_{0}+T_{\mathrm{m}}\right)}{K_{\mathrm{m}}}\right) A \text { if } t>t_{0}+T_{m}
\end{array}
$$

where $A$ is the cell size. Finally, all the elementary discharges provided from each cell at each time are added to obtain the complete hydrograph of the flood.

\subsection{Model calibration and performance indicators}

The model was calibrated through an iterative process using the simplex method developed by Nelder and Mead (Rao, 1978). The Nash-Sutcliffe model efficiency coefficient (Nash and Sutcliffe, 1970) was used to evaluate the agreement between the simulated and the reference runoff hydrograph:

Nash $=1-\frac{\sum_{t=1}^{T}\left(X_{t}^{-} Y_{t}\right)^{2}}{\sum_{t=1}^{T}\left(X_{t}-\bar{X}\right)^{2}}$

where $X_{t}$ and $Y_{t}$ are the observed and simulated discharges at time $t . \bar{X}$ is the mean value of the observed discharges during the event. A Nash coefficient of 1 indicates perfect agreement between the simulated and reference runoff. Since 
the purpose of this study is to focus on the peak of floods, the calibration domain included only the discharges above $40 \mathrm{~m}^{3} \mathrm{~s}^{-1}$ in order to evaluate the model for the highest discharges only and to minimize the influence of the periods with small discharge values.

In addition, several statistics were computed in order to estimate the model efficiency to reproduce the flood peaks and flood volumes, depending on the rainfall input of the model. These statistics include the relative bias (RBIAS), and the relative root mean square error (RRMSE), computed between the observed $Q_{i}$ and estimated $Q e_{i}$ flood peak or volume for each event $i$ :

$\operatorname{RBIAS}[\%]=\frac{1}{N} \sum_{i=1}^{N}\left(\frac{Q_{i}-Q e_{i}}{Q_{i}}\right) 100$

RRMSE $=\sqrt{\frac{1}{N} \sum_{i=1}^{N}\left(\frac{Q_{i}-Q e_{i}}{Q_{i}}\right)^{2}}$

Finally, the efficiency index (EFF) proposed by Aubert et al. (2003) and Brocca et al. (2010) has been used to evaluate the efficiency of spatially distributed rainfall compared to uniform rainfall for flood modeling:

$\mathrm{EFF}=1-\frac{\sum_{t}\left(Q_{\text {spatial }}(t)-Q_{\text {obs }}(t)\right)^{2}}{\sum_{t}\left(Q_{\text {uniform }}(t)-Q_{\text {obs }}(t)\right)^{2}}$

where $t$ is the time, $Q_{\text {obs }}$ the observed discharge, $Q_{\text {spatial }}$ the simulated discharge with spatial rainfall and $Q_{\text {uniform }}$ the simulated discharge with uniform rainfall data. If EFF is greater than 0 then the use of spatially distributed rainfall produces an improvement in the runoff simulation by the model. EFF was calculated only for $Q_{\text {obs }}(t)>40 \mathrm{~m}^{3} \mathrm{~s}^{-1}$.

\section{Study area and hydrological data}

\subsection{The Gardon catchment}

The Gardon at Anduze is a $545 \mathrm{~km}^{2}$ Mediterranean catchment located in the South of France, in the Cévennes mountainous area (Fig. 2). In the Gardon watershed, several studies have been undertaken to estimate the severity of floods (Dolciné et al., 2001; Bouvier et al., 2006; Moussa et al., 2007). The Gardon is a tributary of the Rhone River. The catchment has a contrasted topography, the altitudes range between 120 and $950 \mathrm{~m}$, the slopes are very steep, $20^{\circ}$ in average. The basin has three main geological units; schist (dominant, 60\%), granite and limestone. The soils are relatively thin, from $10 \mathrm{~cm}$ at the top of the hillslopes to $100 \mathrm{~cm}$ close to the river bed. The Gardon is mostly forested with a vegetation cover typical of the Mediterranean area (Moussa et al., 2007), composed of beech, chestnut trees (40\%), holm oaks and garrigue $(22 \%)$, conifers $(17 \%)$, moor $(12 \%)$, pasture and cultivated land $(9 \%)$.

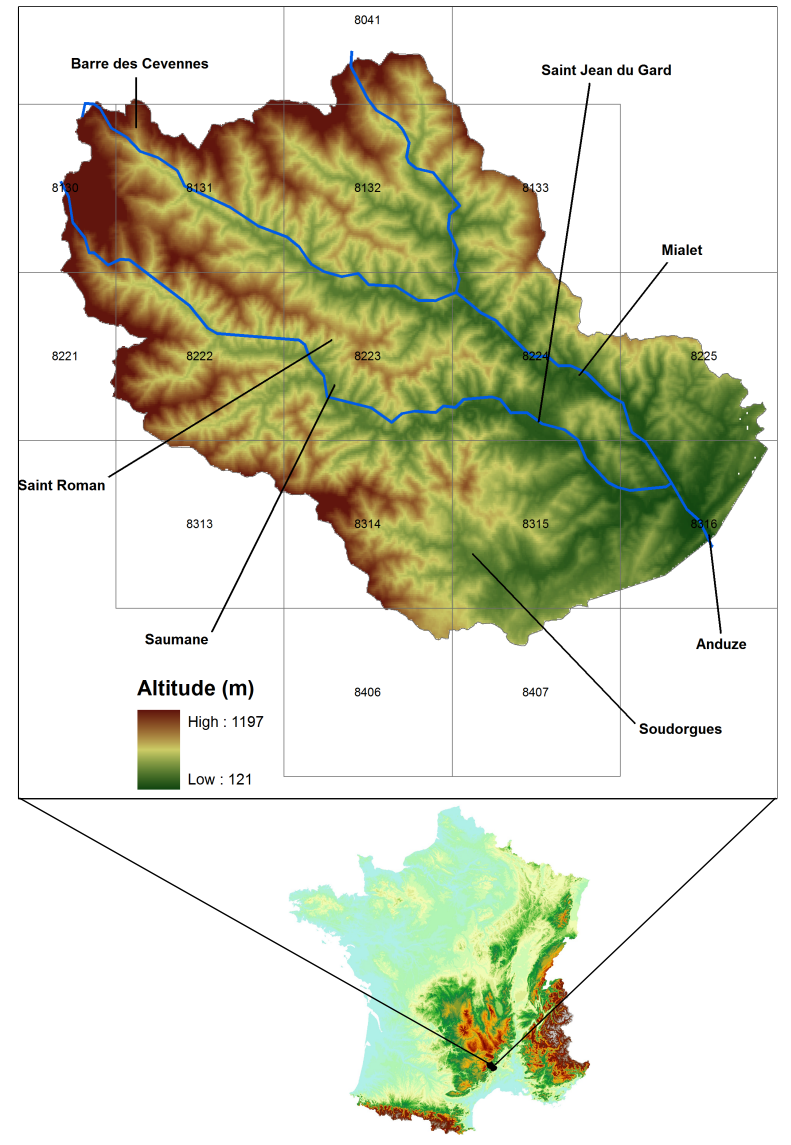

Fig. 2. Location of the Gardon catchment with the 7 rain gauges and the SIM pixels.

The climate is Mediterranean, with frequent heavy storms and intense rainfall in the fall and winter seasons. The floods mainly occur during very intense rainy events that may reach several hundred millimeters in $24 \mathrm{~h}$ (Delrieu et al., 2005). In September 2002, the daily rainfalls reached locally more than $600 \mathrm{~mm}$. Every year, several events exceed a $100 \mathrm{~mm}$ rainfall in $24 \mathrm{~h}$. The flood rising times are short, ranging from 3 to $5 \mathrm{~h}$ in this basin; runoff coefficients depend on rainfall amounts and initial soil moisture conditions, they can reach $0.5-0.6$ in the extreme cases (Bouvier et al., 2006).

\subsection{Hydrological datasets}

The data was provided by the regional flood warning service SPC-GD, ("Service de Prévision des Crues Grand Delta"). The data available was hourly discharge at Anduze and rainfall data from 7 gauges located in the basin as shown on Fig. 2 (Anduze, Barre des Cévennes, Mialet, Saumane, Soudorges, Saint Roman and Saint Jean du Gard). In addition, rainfallradar images at $1-\mathrm{km}$ resolution were provided. The radar operated by Météo-France is located in the city of Manduel, $40 \mathrm{~km}$ south east of Anduze. The radar images provided 

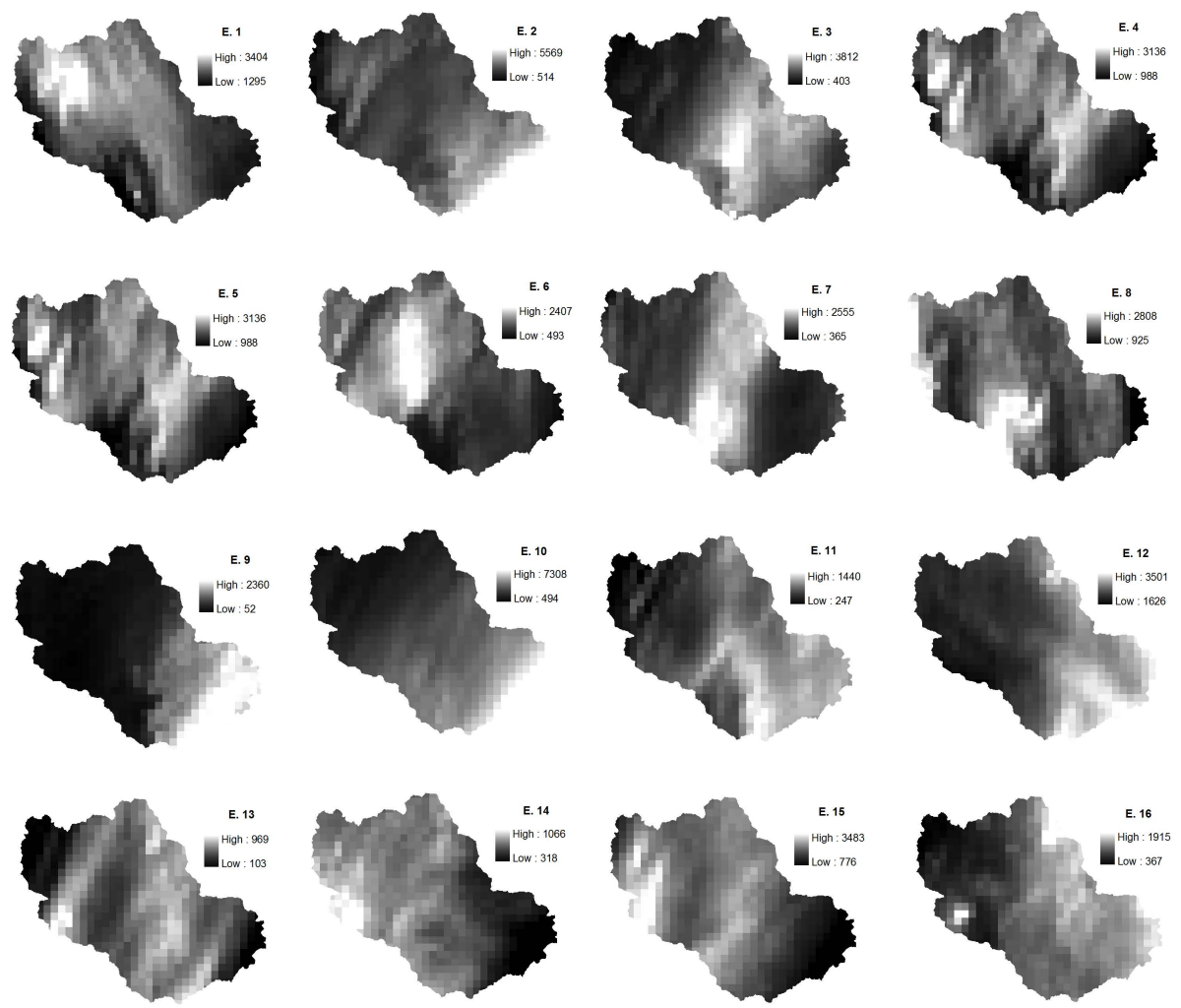

Fig. 3. Radar images of cumulated rainfall for each event (units are in $\mathrm{mm} \times 10$ ).

by the SCP-GD were processed with the software CALAMAR ${ }^{\circledR}$ developed by the RHEA company (Einfalt et al., 1990; Jacquet et al., 2004). The CALAMAR ${ }^{\circledR}$ software produces rainfall estimates obtained from radar images adjusted with a time-varying correction factor, using the rain gauge monitoring network for calibration. The time step for the radar images was originally $5 \mathrm{~min}$; the images have been aggregated at hourly time step matching the one of discharge data.

For this study, 16 flood events on the Gardon of Anduze between 1994 and 2006 were considered. The selected events were those with simultaneous discharge, rain gauge and radar data available. Figure 3 shows the cumulated rainfall for each flood event considered in the present study, obtained with the radar data. Table 1 show some hydrological characteristics of the 16 events, including the duration, the base flow $(\mathrm{BF})$, the peak discharge $(\mathrm{Qm})$, the total precipitation averaged over the 7 rain gauges (Ptot) and the runoff coefficient (RC). The maximum discharge is quite variable, ranging from 151 to $3130 \mathrm{~m}^{3} \mathrm{~s}^{-1}$ for the event of 8 September 2002. The total precipitation observed ranges from 45 to $355 \mathrm{~mm}$ depending in the flood event. As shown in Table 2 , the selected events are well distributed between the different alert levels of the SPC-GD in Anduze, integrating some small floods (green and yellow alert levels) and major floods (orange and red alert levels). All events occurred in the fall season during the months of September October and November, except for two events during the months of March and May.

\subsection{SIM soil moisture output}

The output from a hydro-meteorological model, SIM, was used to characterize soil moisture. The SIM model was developed by Météo-France and enables the soil wetness index to be computed for the whole France. SIM is based on the coupling of three different models at a scale of $8 \times 8 \mathrm{~km}^{2}$ : SAFRAN, which produces the meteorological input, ISBA, which deals with both mass and energy fluxes between the atmosphere, vegetation and soils and MODCOU, which routes both superficial and groundwater discharges. A complete description of the SIM model can be found in Habets et al. (2008) and Quintana Seguí et al. (2009). The model combines elevation, land cover and soil characteristics with atmospheric input to estimate river flow. Among other variables, SIM can reproduce the soil moisture conditions. ParisAnguela et al. (2008) found good agreement between the soil moisture output of the SIM model and local soil moisture measurements or ERS-scatterometer data. The percentage of soil saturation is available daily at 08:00 h (winter time) for cells of $8 \times 8 \mathrm{~km}^{2}$ at three different levels in the soils: surface layer, root layer and deep layer (levels are respectively 0.1 , 
Table 1. Characteristics of the selected flood events.

\begin{tabular}{lllrrrrrr}
\hline Event & Date & $\begin{array}{c}\text { Duration } \\
(\mathrm{h})\end{array}$ & $\begin{array}{r}\text { Base Flow } \\
(\mathrm{m} 3 / \mathrm{s})\end{array}$ & $\begin{array}{r}\text { Peak } \\
\text { discharge } \\
(\mathrm{m} 3 / \mathrm{s})\end{array}$ & $\begin{array}{c}\text { Total rainfall } \\
\text { with rain } \\
\text { gauges }(\mathrm{mm})\end{array}$ & $\begin{array}{c}\text { Total rainfall } \\
\text { with radar } \\
(\mathrm{mm})\end{array}$ & $\begin{array}{c}\text { Runoff } \\
\text { coefficient }\end{array}$ & $\begin{array}{c}\text { Hu2 } \\
(\%)\end{array}$ \\
\hline 1 & 22 September 1994 & 101 & 9.7 & 670 & 256.8 & 280.7 & 0.30 & 47.6 \\
2 & 3 October 1995 & 68 & 38.0 & 1610 & 286.2 & 342.0 & 0.48 & 56.8 \\
3 & 13 October 1995 & 39 & 27.0 & 1410 & 196.7 & 265.9 & 0.46 & 63.8 \\
4 & 24 November 1995 & 169 & 95.0 & 450 & 132.1 & 121.7 & 0.51 & 60.8 \\
5 & 10 November 1996 & 110 & 0.8 & 380 & 185.5 & 248.6 & 0.15 & 55.4 \\
6 & 17 May 1999 & 197 & 13.5 & 620 & 163.9 & 163.9 & 0.75 & 56.5 \\
7 & 19 September 2000 & 20 & 11.1 & 340 & 104.5 & 155.7 & 0.08 & 39.8 \\
8 & 28 September 2000 & 64 & 3.4 & 1190 & 203.3 & 232.4 & 0.30 & 51.7 \\
9 & 14 March 2002 & 83 & 10.0 & 640 & 54.5 & 99.7 & 0.59 & 56.2 \\
10 & 8 September 2002 & 32 & 2.8 & 3130 & 355.8 & 426.6 & 0.32 & 48.1 \\
11 & 27 Octoer 2004 & 42 & 15.4 & 236 & 115.6 & 123.7 & 0.22 & 57.1 \\
12 & 5 September 2005 & 85 & 8.9 & 151 & 262.9 & 326.0 & 0.10 & 38 \\
13 & 3 November 2005 & 34 & 23.9 & 195 & 45.1 & 57.3 & 0.31 & 62.8 \\
14 & 23 September 2006 & 22 & 1.9 & 166 & 77.3 & 82.9 & 0.09 & 52.6 \\
15 & 18 October 2006 & 47 & 2.3 & 1250 & 222.3 & 250.9 & 0.42 & 57.2 \\
16 & 14 November 2006 & 119 & 5.5 & 256 & 100.1 & 126.9 & 0.19 & 56.2 \\
\hline
\end{tabular}

Table 2. Alerts levels of the SPC-GD at Anduze.

\begin{tabular}{lrr}
\hline Alert level & Discharge $\left(\mathrm{m}^{3} / \mathrm{s}\right)$ & Event number \\
\hline Green & $<500$ & $4,5,7,11,12,13,14,16$ \\
Yellow & 500 et 1200 & $1,6,9$, \\
Orange & 1200 et 2000 & $2,3,8,15$ \\
Red & $>2000$ & 10 \\
\hline
\end{tabular}

1.9 and $2.7 \mathrm{~m}$ for the Gardon catchment). The soil depths were supplied by the ECOCLIMAP database, which characterizes the soil and vegetation parameters at a $1 \mathrm{~km}^{2}$ scale (Habets et al., 2008). Paris-Anguela et al. (2008) have shown that the estimation of the root-zone moisture is better than the estimation obtained for surface soil moisture. The difference can be explained by the fact that surface soil moisture is more affected by atmospheric conditions than root-zone soil moisture. Marchandise and Viel (2009) also noted that the soil moisture of the root layer (Hu2) was the most suitable for hydrological applications. Consequently in this study, only the soil saturation $\mathrm{Hu} 2(\%)$ of the intermediate layer was considered:

$\mathrm{Hu} 2=\frac{\theta}{\theta_{s}} \cdot 100$

where $\theta$ denotes the volumetric water content and $\theta_{s}$ the saturated volumetric water content.

As shown on Fig. 4, the SIM model is able to reproduce the annual pattern of soil moisture on a daily scale. A typical Mediterranean pattern with the highest moisture observed during the fall and winter season and very dry during summer months can be seen. Depending on the year (the years 2004

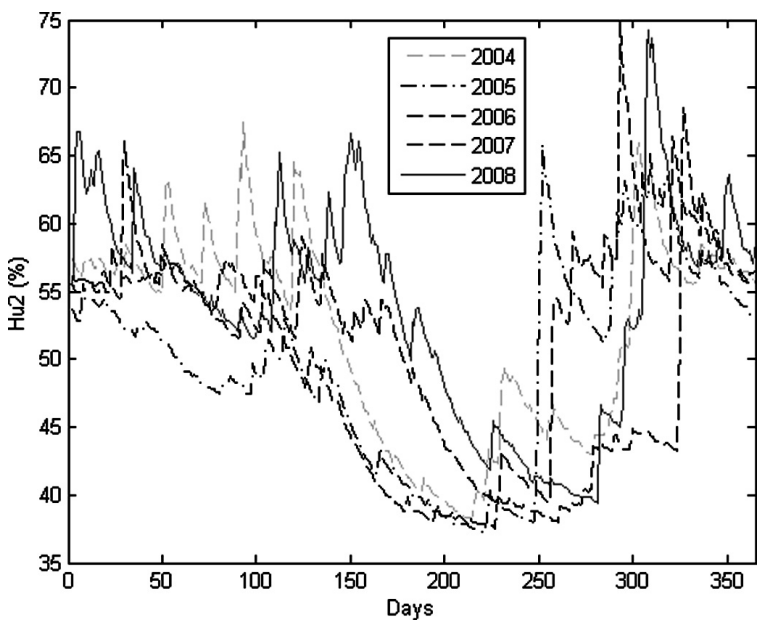

Fig. 4. Averaged Hu2 values over the Gardon of Anduze catchment (2004-2008).

to 2008 are presented in Fig. 4), the annual pattern is subject to changes in time depending on the beginning of the rainy season in fall. Hu2 values range from $35 \%$ to $75 \%$, which means that the soils are never absolutely dry, or saturated on the whole pixel scale. For the 16 flood events considered in the study, the Hu2 showed little spatial variability in between the cells of the SIM output available covering the Gardon of Anduze watershed area (Fig. 2), with a coefficient of variation between 0.05 and 0.12 . The data of the different cells were averaged in order to obtain one single soil moisture descriptor over the basin for each flood event (Table 1). 

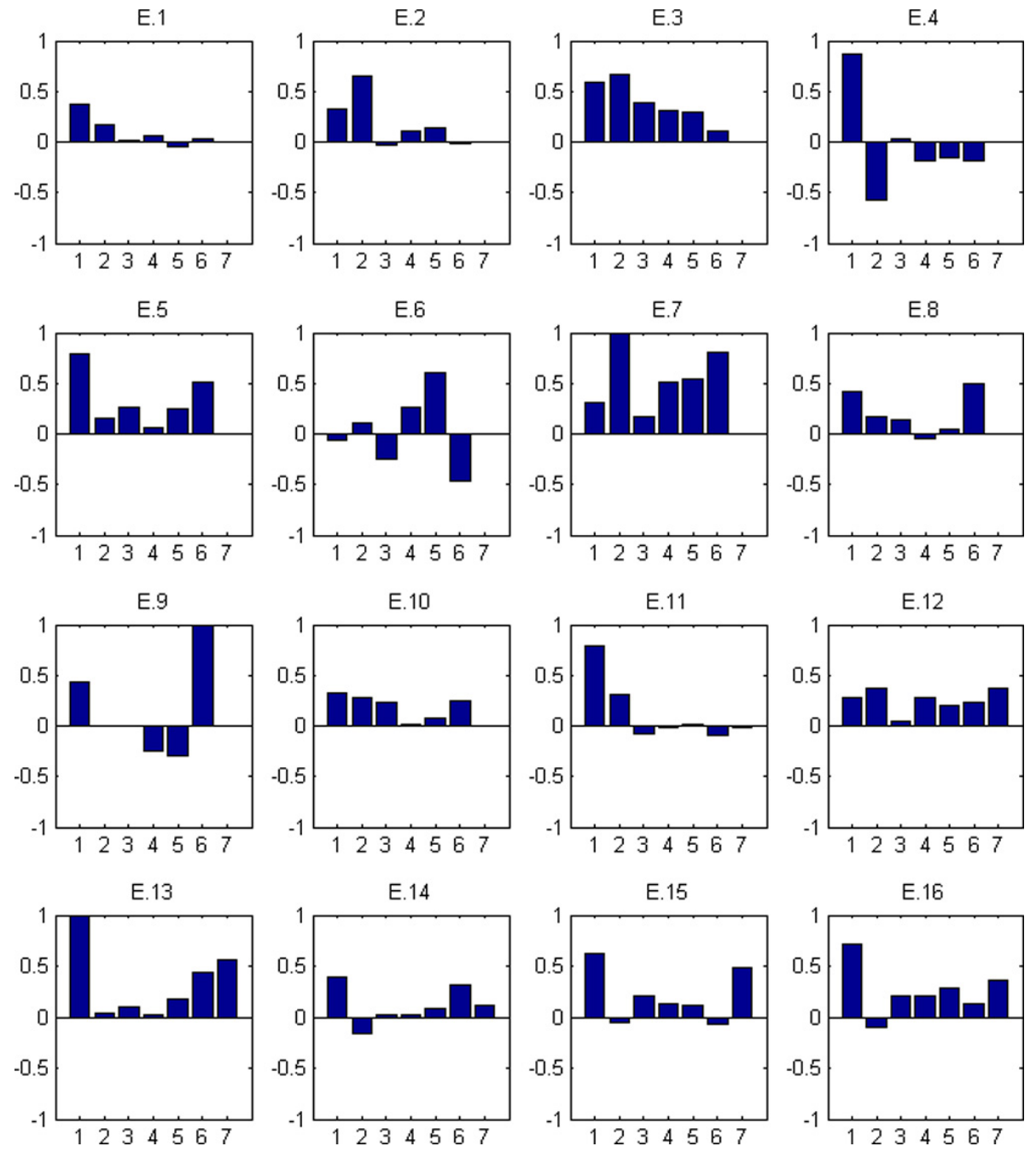

Fig. 5. Relative difference of total rainfall for each event computed between radar rainfall data and corresponding rain gauges 1 to 7 (1-Anduze, 2-Barre, 3-Mialet, 4-Roman, 5-Saumane, 6-Soudorgues and 7-St-Jean).

\section{Results and discussion}

\subsection{Comparison of rain gauge and gridded radar rainfall data}

Radar rainfall measurements need to be corrected from rain gauges measurements, as stated by Creutin et al. (1997), Hardegree et al. (2008), and Wagener et al. (2007). Although the radar data were already corrected from rain gauges measurements, a new control was effected by a comparison of the rain gauge and gridded radar rainfall data. Each pixel of the radar data images corresponding to the 7 available rain gauges was identified. The cumulative rainfall over these pixels for each event was extracted and compared with the cumulative rainfall recorded in the corresponding rain gauge. A relative bias was computed in order to assess the differences between the two rainfall estimates. The results indicated that the radar precipitation overestimated (in average by $23 \%$ ) the rain gauges precipitation. Depending on the event considered, the bias could range from $-60 \%$ to $100 \%$ or above for a few cases. For the majority of cases, there is a systematic positive bias towards higher amounts of precipitation when using the radar data (Fig. 5). The differences between the two rainfall estimates are probably due to the fact that the Gardon catchment is located quite far away from the radar ( 40 to $80 \mathrm{~km}$ ), which can seriously affect radar efficiency in a mountainous area. These results are coherent with the results obtained in others studies. Creutin et al. (1997) reported for the Gardon of Anduze catchment a significant statistical difference between ground and radar measurements (after correction). Similarly, Hardegree et al. (2008) found that radar data for the Snake River Plain of south-western Idaho overestimated cumulative gauge precipitation by $20 \%-40 \%$. 


\subsection{Rainfall-runoff modeling results using different precipitation inputs}

The event-based rainfall-runoff model as described in the Sect. 2 was used with the different precipitation data inputs available. The different precipitation inputs used with the SCS-LR model over the Gardon watershed were:

1. The uniform precipitation based on areal mean of the 7 rain gauge data (UG).

2. The uniform precipitation based on areal mean of the radar data (UR).

3. The 7 rain gauge data spatially interpolated (SG).

4. The radar data at $1-\mathrm{km}$ resolution (SR).

All four precipitation datasets were used at 1-hour time resolution to provide comparable estimates. The model was calibrated using the available discharge data for each event. Both parameters $d s$ and $K_{0}$ were set constant for all the events, because (i) they were found to vary little from an event to another, and (ii) to reduce the possible sources of equifinallity when calibrating the whole set of parameters, and therefore, to make the calibration of $S$ and $V_{0}$ more robust. The $d s$ parameter was obtained from the recession curves of the observed flood hydrographs and was set to the median value of 0.4 for all events. The parameter $K_{0}$ was also set constant for all events with $K_{0}=1.5$, the optimal value obtained for this catchment in previous runs of the model. The $S$ and $V_{0}$ parameters were calibrated for each event using the four different rainfall inputs.

\subsubsection{Impact on model parameters}

Figure 6a shows the distribution of the optimal $V_{0}$ parameters obtained for all the events with the different rainfall inputs. The median $V_{0}$ values obtained with the 4 rainfall inputs used are different, with median $V_{0}$ values of respectively 3.08 and 3.17 for the uniform rainfall inputs UG and UR, and median $V_{0}$ values of 2.63 and 2.74 for the rainfall inputs SG and SR. On average, $V_{0}$ values tend to be larger when using the uniform precipitation inputs UG and UR, as indicated by their higher median. The reason is that uniform rainfall tends to artificially diffuse the real rainfall over the whole catchment, and then it is necessary to increase the $V_{0}$ parameter for hydrograph reshape. There is also a larger spread in the $V_{0}$ values when using the uniform rainfall inputs UG and UR compared to $V_{0}$ values obtained with the spatial rainfall inputs SG and SR (Fig. 6). This finding is coherent with Arnaud et al. (2002) who observed that the calibration of a rainfall-runoff model is affected when using an averaged uniform rainfall input; the generated biases have consequences for the numerical stability of the model parameters and increase parameter uncertainty. Similarly, Cole and Moore (2008) or Bárdossy and Das (2008) results indicate
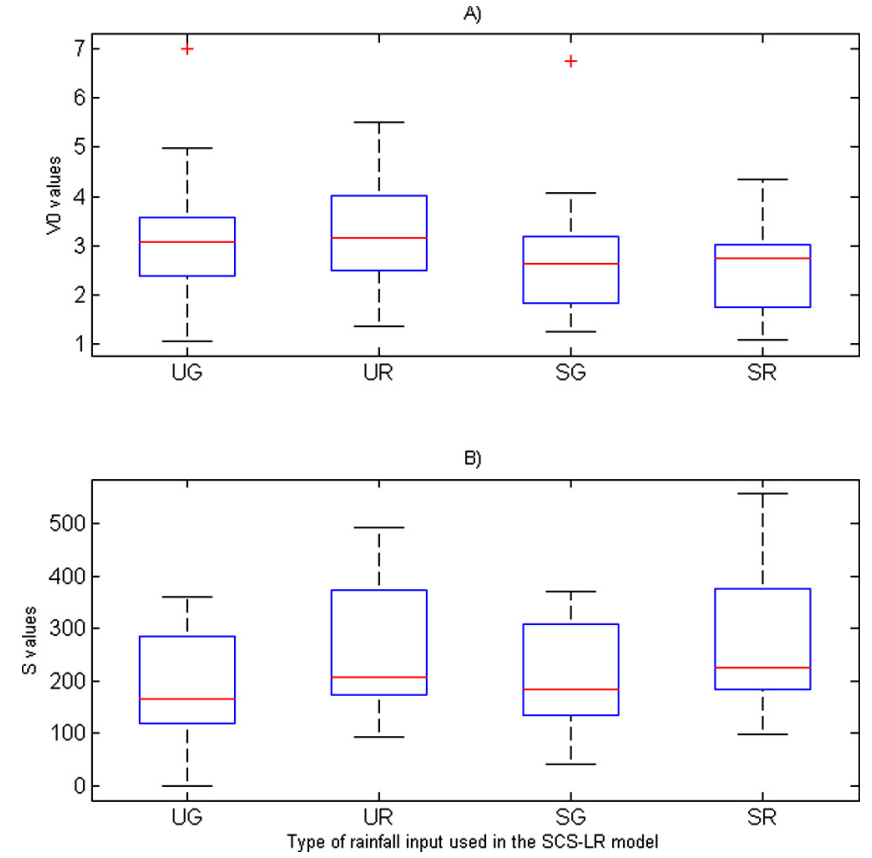

Fig. 6. Box-plot of $V_{0}$ (a) and $\mathrm{S}$ (b) values for each rainfall input in the rainfall-runoff model (the box has lines representing the lower quartile, median and upper quartile values).

that a model using different rainfall spatial resolutions might need re-calibration of the model parameters.

The $S$ parameter varies from 0 to $557 \mathrm{~mm}$ depending on the event (Fig. 6b). Larger $S$ values are obtained with the models using radar data comparison with the models using rain gauge data, either averaged or spatially distributed. This is in agreement with the fact that the total precipitation is on average $23 \%$ greater when using radar data over the rain gauge data. In addition, the $S$ values are underestimated when considering uniform rainfall compared to distributed rainfall, with $S$ values smaller for the rainfall data UG and UR than for the rainfall inputs SG and SR, respectively. Moreover, no dependencies have been observed between $S$ and $V_{0}$ values for all the rainfall inputs.

\subsubsection{Impact on flood simulations}

The median Nash coefficients, the relative bias and RMSE on runoff volume and peak flow of the flood simulations with the different rainfall inputs are presented in Table 3. In Fig. 7 the Nash coefficients obtained for each event with rain gauge data (uniform or spatially distributed) and the radar data (uniform or spatially distributed) are plotted. These results show that using spatially distributed rainfall data potentially improves the simulations, with higher median Nash values obtained with SG and SR (respectively 0.86 and 0.81 , Table 3 ). The median Nash values obtained with uniform rainfall data are lower, respectively 0.77 and 0.76 for UG and UR. On 

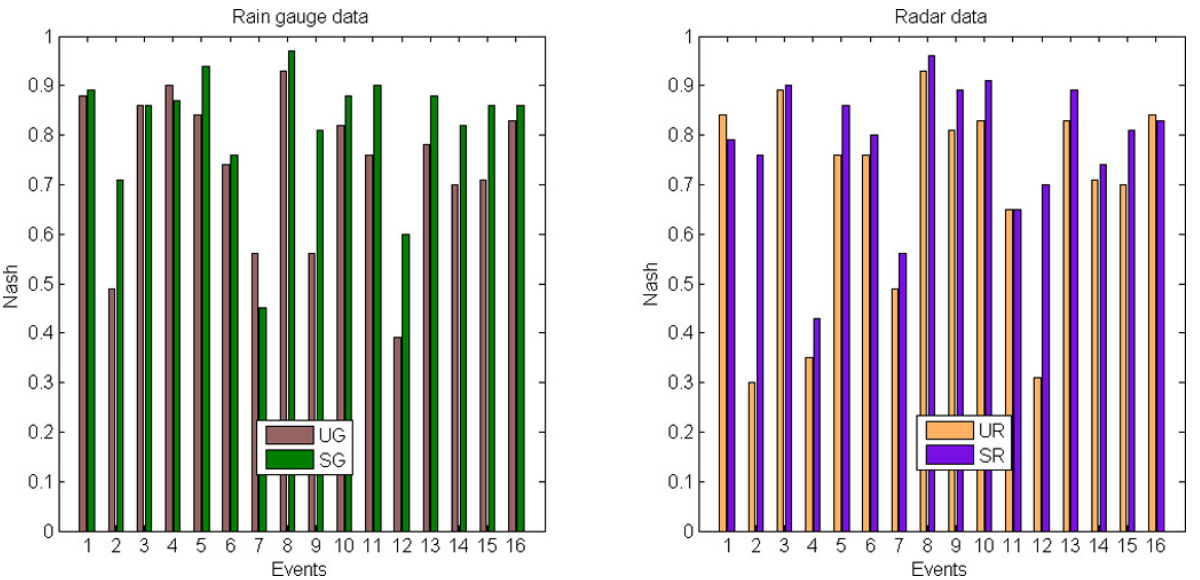

Fig. 7. Nash values for each event using uniform mean areal rainfall of spatially distributed rainfall from rain gauge data (left) or radar data (right).

Table 3. Results of rainfall-runoff modeling using four different rainfall inputs (UG, UR, SG, SR).

\begin{tabular}{lrrrrr}
\hline $\begin{array}{l}\text { Rainfall } \\
\text { input }\end{array}$ & $\begin{array}{r}\text { RBIAS } \\
\text { Volume } \\
(\%)\end{array}$ & $\begin{array}{r}\text { RBIAS } \\
\text { PeakFlow } \\
(\%)\end{array}$ & $\begin{array}{r}\text { RRMSE } \\
\text { Volume } \\
(\%)\end{array}$ & $\begin{array}{r}\text { RRMSE } \\
\text { PeakFlow } \\
(\%)\end{array}$ & $\begin{array}{r}\text { Median } \\
\text { Nash }\end{array}$ \\
\hline UG & -0.05 & -0.20 & 0.20 & 0.22 & 0.77 \\
UR & -0.07 & -0.19 & 0.14 & 0.23 & 0.76 \\
SG & -0.10 & -0.13 & 0.15 & 0.19 & 0.86 \\
SR & -0.07 & -0.12 & 0.13 & 0.19 & 0.81 \\
\hline
\end{tabular}

average, the use of spatial rainfall improves the Nash coefficients by $8.7 \%$. The errors in flood volume and peak flow are also reduced when using spatial rainfall data (SG and $\mathrm{SR}$ ) compared to uniform rainfall data (UG and UR). This result is in agreement with Andréassian et al. (2004), who observed an improvement of the streamflow simulations on virtual catchments when taking into account the spatial representation of precipitation.

When considering each of the 16 flood events (Fig. 7), it can be seen that the Nash coefficients obtained with spatially distributed rainfall are higher than those obtained with uniform rainfall for 14 events out of 16 for both rainfall inputs (rain gauge and radar). The event 7 has the lowest Nash values, below 0.6 with all the different rainfall inputs, indicating probably some inadequate rain estimation with both rain gauge and radar data. For the events 2 and 12, with localized rainfall at the southern edge of the catchment (Fig. 3), a great improvement in the flood simulations is observed when using the distributed rainfall inputs, with Nash coefficients increasing from 0.3 to 0.7 . For some of the most important events (corresponding to the orange and red alerts level, Table 2), better simulations are obtained with spatial rainfall as shown on Fig. 8. Saulnier and Le Lay (2009) and Bonnifait et al. (2009) have also previously concluded in their analyses of the 8 September 2002 event that the accurate geographi- cal localization of the storm cells was needed to improve the discharge simulations.

The performance of the model with spatial rain gauge or radar data is very similar, with a lower mean Nash coefficient $(0.81)$ with radar data but the model using the radar rainfall data yields almost the same values of RBIAS and RRMSE on peak discharge or runoff volume as shown on Table 3. These similar results for modeling efficiency must be considered as the fact that 7 rain gauges are available in the catchment, allowing a fair estimation of the rainfall on the catchment scale; the efficiency of the radar rainfall input would have been more conclusive in the case of a reduced density of rain gauges. These results are similar to those obtained by Borga (2002) in South-West England, or Carpenter et al. (2001) in the south United-States, indicating that hydrograph predictions driven by radar data may attain simulation efficiencies close to those obtained from the gauge-based reference rainfall.

\subsection{Impact of the spatial distribution of rainfall on the relationships between $S$ and antecedent soil moisture conditions}

Using the flood simulations obtained with rainfall inputs UG, UR, SG and SR, the $S$ parameter describing the soil potential 

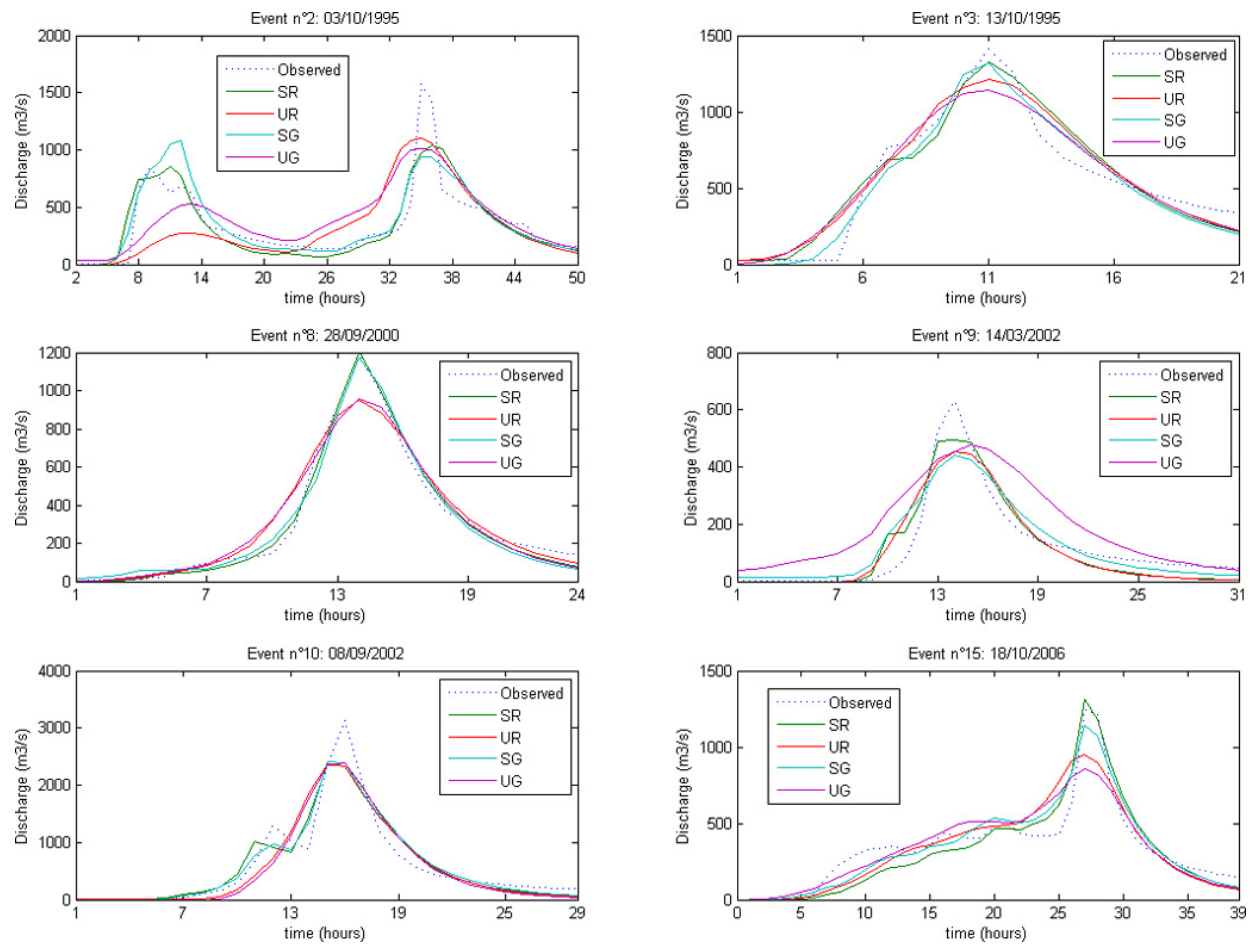

Fig. 8. Simulated and observed flood hydrographs for the 6 most important events, corresponding to the alerts level "orange" and "red", using the different rainfall inputs.
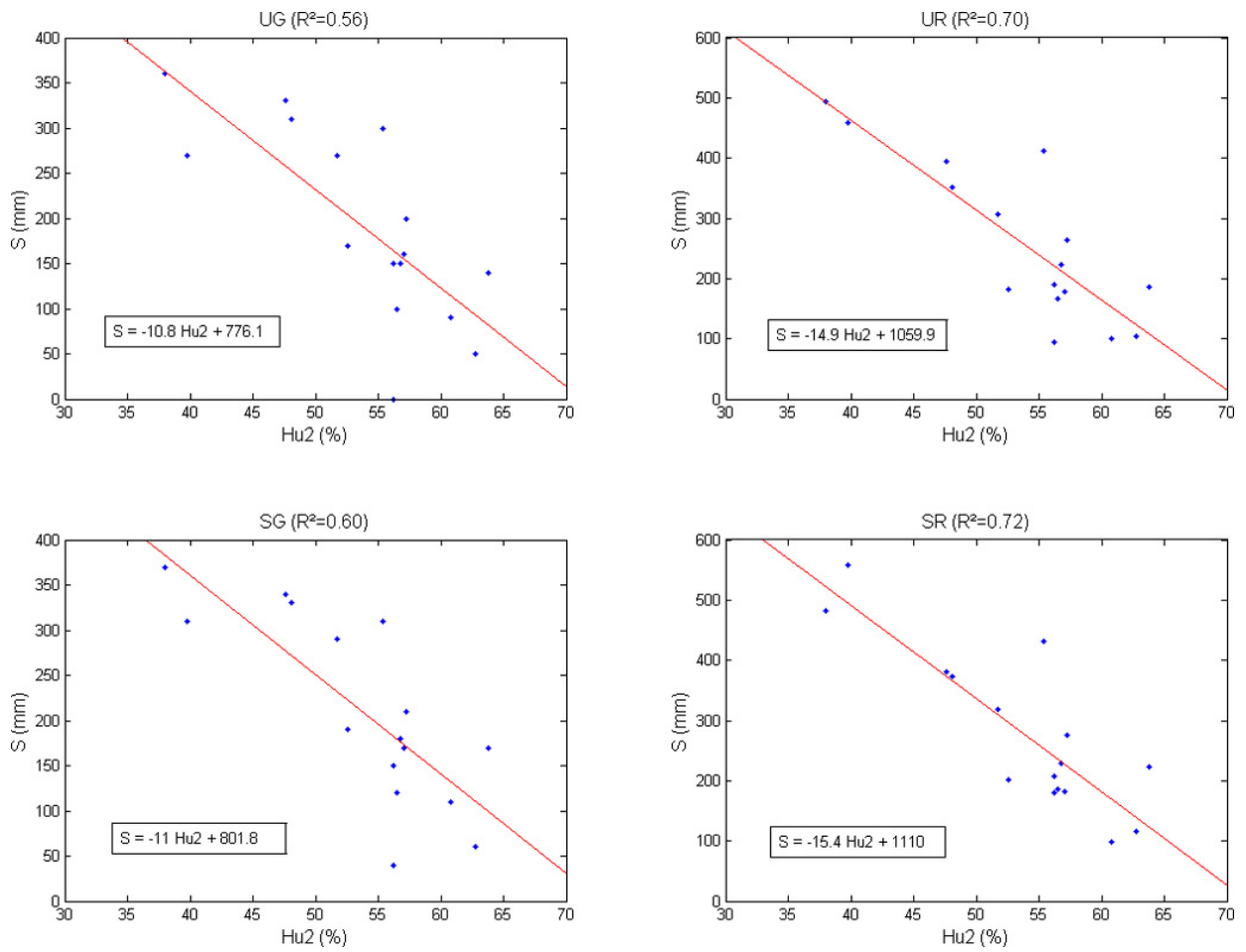

Fig. 9. Relation between $S$ and $\mathrm{Hu} 2$ for each rainfall input. 

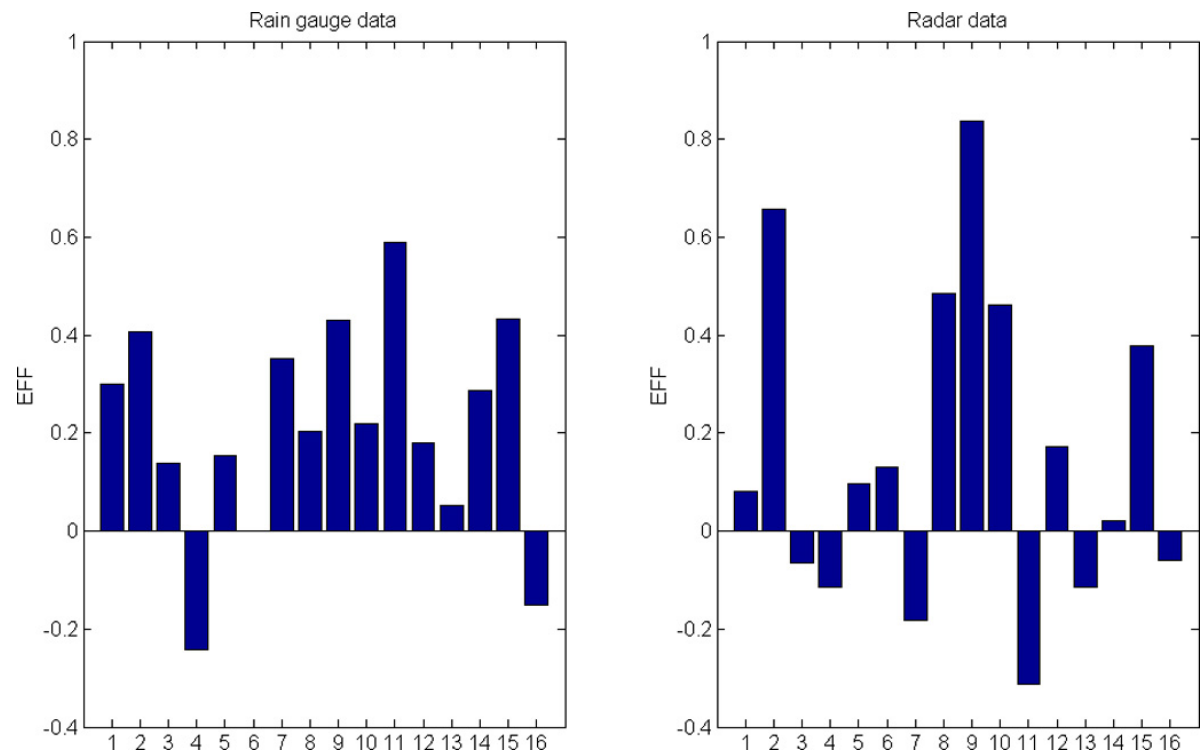

Fig. 10. EFF index between uniform or spatially distributed rainfall data with rain gauge data (left) and radar data (right).

maximum water retention has been compared to the $\mathrm{Hu} 2 \mathrm{pa}$ rameter obtained from the SIM model. $\mathrm{Hu} 2$ values vary from one event to another as shown in Table 1, indicating a range of different initial moisture conditions. The plots of the relationships between $\mathrm{Hu} 2$ and $S$ derived with UG, UR, SG and SR are presented in Fig. 9. Direct linear relationships exist between the $S$ parameters obtained with the different rainfall inputs and the $\mathrm{Hu} 2$ values for each event, with $R^{2}$ values ranging from 0.56 to 0.72 . The results indicate an improvement of the $S$-Hu2 relationships when using spatial rainfall data instead of uniform mean areal rainfall, for each given input type (SG better than UG; SR better than UR). However, the best $R^{2}$ are obtained with the radar rainfall data, with $R^{2}$ values of respectively 0.70 and 0.72 with UR and SR. The relationships shown in Fig. 9 are identical to the relationships obtained by Tramblay et al. (2010) for a small $\left(4 \mathrm{~km}^{2}\right)$ sub-catchment of the Gardon; furthermore, Marchandise and Viel (2009) reported significant correlations between $\mathrm{Hu} 2$ and $S$ for different catchments in southern France with $R^{2}$ values ranging from 0.25 to 0.73 .

\subsection{Global impact of the spatial distribution of rainfall on flood simulations}

The impact of using spatially distributed rainfall inputs on model performances and $S$-Hu2 relationships was analyzed separately in the sections above. In this last section, both impacts are combined in order to assess the relative efficiency of spatially distributed rainfall for flood modelling. Consequently, the model is applied with the $S$ parameter estimated from the $S$-Hu2 relationships established in the Sect. 4.3 (Fig. 9), for each rainfall input. The values of the $V_{0}$ parameter obtained previously for each event and each rainfall input (see Sect. 4.2.1) were kept unchanged. The results indicate that the models using spatial rainfall perform better than the models using uniform rainfall, with the median Nash values for the SG and SR inputs respectively equal to 0.55 and 0.52 , and median Nash values for the UG and UR inputs respectively equal to 0.45 and 0.43 . The EFF index has been computed using the Eq. (10) in order to compare the relative efficiency of spatially distributed rainfall for runoff simulation. Figure 10 shows the results obtained with rain gauge and radar data, indicating for most events, in particular when using rain gauge data, better runoff modeling efficiency with spatially distributed rainfall data (with $\mathrm{EFF}>1$ ). On average, the use of spatially distributed rainfall improves the runoff simulation by $21 \%$ when using rain gauge data, and by $15 \%$ when using radar data.

\section{Summary and conclusions}

This paper compared spatially distributed rainfall and mean areal rainfall as inputs in an event-based rainfall-runoff modeling approach. On the basis of the analyses and the results reported in this study, it can be concluded that spatial rainfall increases the efficiency of the model. The best benefits of using spatial rainfall data have been obtained for some of the largest flood events; on average for all the flood events the Nash coefficient is $8.7 \%$ larger when using spatial rainfall instead of uniform rainfall. In addition, the relationship between the $S$ parameter, describing the initial condition of the model, and an external predictor of soil moisture, here the $\mathrm{Hu} 2$ parameter of the SIM model, is better when using spatial rainfall, in particular when using radar data with $R^{2}$ values increasing from 0.56 to 0.72 . Radar rainfall data also 
provides very similar modeling results to the relatively dense rain gauge data network available for the Gardon catchment, proving its usefulness for forecasting. The calibration of the model was unable to compensate for the bias in the model induced by the uniform rainfall compared to the spatially distributed rainfall. If the $S$ parameter is estimated from the Hu2 soil moisture index, the flood simulations with spatially distributed rainfall are improved by $21 \%$ compared to the simulations obtained with uniform rainfall, with rain gauge data, and by $15 \%$ with radar data. Testing the rainfall-runoff model on a range of different flood events gives a good representation of the model parameters and therefore reduces the uncertainty on their estimation for future events.

The Hu2 parameter of the SIM model provides a valid soil moisture descriptor to be used in the rainfall-runoff modeling of flood events. For operational applications, the possibility to extrapolate the relationship between the soil moisture simulated by the SIM model (Hu2) and the initial conditions of the SCS model can be very useful, not only for flood forecasting but also for runoff estimation in ungauged catchments. It captures adequately the temporal evolution of the soil moisture and therefore is useful for defining the initial soil moisture conditions prior to a flood event. In order to obtain better modeling results and in particular for flood forecasting, there is a need to take into account both the spatial variability of rainfall and soil moisture in the model, in particular for large catchments. This could be accomplished in a fully distributed modeling approach incorporating both spatially distributed rainfall and soil moisture over the watershed.

Acknowledgements. The authors would like to thank the SCHAPI for providing the datasets in the context of the BNVE project. The authors wish also to thank Guy Jacquet (RHEA) for providing technical information on the CALAMAR $®$ radar data. Thanks are also due to Anne Crespy and Agnes Cres for their help with the ATHYS modeling platform. The authors also extend their thanks to the handling Editor: Fabio Castelli, and two anonymous reviewers for their constructive comments and suggestions on the earlier draft of the paper. This study was supported by the French "Observatoire Hydro-Météorologique Cévennes-Vivarais” (OHM-CV).

Edited by: F. Castelli

Reviewed by: two anonymous referees

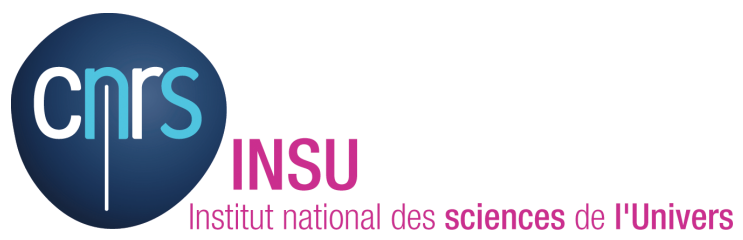

The publication of this article is financed by CNRS-INSU.

\section{References}

Andréassian, V., Perrin, C., Michel, C., Usart-Sanchez, I., and Lavabre, J.: Impact of imperfect rainfall knowledge on the efficiency and the parameters of watershed models, J. Hydrol., 250, 206-223, 2001.

Andréassian, V., Oddos, A., Michel, C., Anctil, F., Perrin, C., Loumagne, C.: Impact of spatial aggregation of inputs and parameters on the efficiency of rainfall-runoff models: A theoretical study using chimera watersheds, Water Resour. Res., 40, doi:10.1029/2003WR002854, 2004.

Aubert, D., Loumagne, C., and Oudin, L.: Sequential assimilation of soil moisture and streamflow data in a conceptual rainfallrunoff model, J. Hydrol., 280, 145-161, 2003.

Arnaud, P., Bouvier, C., Cisneros, L., and Dominguez, R.: Influence of rainfall spatial variability on flood prediction, J. Hydrol., 260, 216-230, 2002.

Bárdossy, A. and Das, T.: Influence of rainfall observation network on model calibration and application, Hydrol. Earth Syst. Sci., 12, 77-89, doi:10.5194/hess-12-77-2008, 2008.

Beck, H. E., de Jeu, R. A. M., Schellekens, J., van Dijk, A. I. J. M., and Bruijnzeel, L. A.: Improving Curve Number based storm runoff estimates using soil moisture proxies, IEEE J. Sel. Top. Applied Earth Observation and Remote Sensing, 2(4), 19391404, 2010.

Berthet, L., Andréassian, V., Perrin, C., and Javelle, P.: How crucial is it to account for the Antecedent Moisture Conditions in flood forecasting? Comparison of event-based and continuous approaches on 178 catchments, Hydrol. Earth Syst. Sci. 6, 17071736, 2009.

Bentura, P. L. and Michel, C.: Flood routing in a wide channel with a quadratic lag-and-route method, Hydrolog. Sci. J., 42 , 169189, 1997.

Bonnifait, L., Delrieu, G., Le Lay, M., Boudevillain, B., Masson, A., Belleudy, P., Gaume, E., and Saulnier, G-M.: Distributed hydrologic and hydraulic modeling with radar rainfall input: Reconstruction of the 8-9 September 2002 catastrophic flood event in the Gard region, France, Adv. Water Resour., 32, 1077-1089, 2009.

Borga, M.: Accuracy of radar rainfall estimates for streamflow simulation, J. Hydrol., 267, 26-39, 2002.

Bouvier, C., Ayral, P. A., Brunet, P., Crespy, A., Marchandise, A., and Martin, C.: Recent advances in rainfall-runoff modeling: Extrapolation to extreme floods in southern France, Proceedings of AMHY-FRIEND International workshop on Hydrological extremes, Rende, Italia, 2006.

Brocca, L., Melone, F., Moramarco, T., and Singh, V. P.: Assimilation of observed soil moisture data in storm rainfall runoff modelling. J. Hydrol. Engng., 14(2), 153-165, 2009a.

Brocca, L., Melone, F., Moramarco, T., and Morbidelli, R.: Antecedent wetness conditions based on ERS scatterometer data, J. Hydrol., 364(1-2), 73-87, 2009b.

Brocca, L., Melone, F., Moramarco, T., Wagner, W., Naeimi, V., Bartalis, Z., and Hasenauer, S.: Improving runoff prediction through the assimilation of the ASCAT soil moisture product, Hydrol. Earth Syst. Sci., 14, 1881-1893, doi:10.5194/hess-141881-2010, 2010.

Carpenter, T. M., Georgakakos, K. P., and Sperfslaga, J. A.: On the parametric and NEXRAD-radar sensitivities of a ditributed hydrologic model suitable for operational use, J. Hydrol., 253, 
169-193, 2001.

Cole, S. J. and Moore, R. J.: Hydrological modelling using raingauge- and radar-based estimators of areal rainfall, J. Hydrol., 358, 159-181, 2008.

Creutin, J. D., Andrieu, H., and Faure, D.: Use of weather radar for the hydrology of a mountainous area, Part II: Radar measurement validation, J. Hydrol. 193, 26-44, 1997.

Delrieu, G., Ducrocq, V., Gaume, E., Nicol, J., Payrastre, O., Yates, E., Kirstetter, P.E., Andrieu, H., Ayral, P. A., Bouvier, C., Creutin, J. D, Livet, M., Anquetin, S., Lang, M., Neppel, L., Obled, C., Parent-du-Chatelet, J., Saulnier, G. M., Walpersdorf, A., and Wobrock, W.: The catastrophic flash-flood event of 8-9 September 2002 in the Gard region, France: a first case study for the Cévennes-Vivarais Mediterranean Hydro-meteorological Observatory, J. Hydrometeorol., 6, 34-52, 2005.

Delrieu, G., Braud, I., Berne, A., Borga, M., Boudevillain, B., Fabry, F., Freer, J., Gaume, E., Nakakita, E., Seed, A., Tabary, P., and Uijlenhoet, R.: Weather radar and hydrology, Adv. Water Resour., 32, 969-974, 2009.

Dolciné, L., Andrieu, H., Sempere-Torres, D., and Creutin, D.: Flash flood forecasting with coupled precipitation model in mountainous Mediterranean basin, J. Hydrol. Engng. ASCE, 6, $1-10,2001$

Einfalt T., Denoeux T., and Jacquet G.: A radar rainfall forecasting method designed for hydrological purposes, J. Hydrol., 114, 229-244, 1990.

Gaume E., Livet M., Desbordes M., and Villeneuve J. P.: Hydrological analysis of the river Aude, France, flash flood on 12 and 13 November 1999, J. Hydrol., 286, 135-154, 2004.

Habets, F., Boone, A., Champeaux, J. L., Etchevers, P., Franchisteguy, L., Leblois, E., Ledoux, E., Le Moigne, P., Martin, E., Morel, S., Noilhan, J., Segui, P. Q., Rousset-Regimbeau, F., Viennot, P.: The SAFRAN-ISBA-MODCOU hydrometeorological model applied over France, J. Geophys. Res. 113, D06113, doi:10.1029/2007JD008548, 2008.

Hardegree, S. P., Van Vactor S. S., Levinson, D. H., and Winstral, A. H.: Evaluation of NEXRAD Radar Precipitation Products for Natural Resource Applications, Rangeland Ecol. Manag., 61(3), 346-353, 2008

Huang, M., Gallichand, J., Dong, C., Wang, Z., and Shao, M.: Use of soil moisture data and curve number method for estimating runoff in the Loess Plateau of China, Hydrol. Processes, 21(11), 1471-1481, 2007.

Javelle, P., Fouchier, C., Arnaud, P., and Lavabre, J.: Flash flood warning at ungauged locations using radar rainfall and antecedent soil moisture estimations, J. Hydrol., 397, 267-274, 2010

Jacquet, G., Piatyszek, E., and Lyard, S.: Radar-Based Rainfall Input Requirements: Synthesis of US and French 10 Years Experience. in: Global Solutions for Urban Drainage, Proceedings of 9th International Conference on Urban Drainage (9ICUD), doi:10.1061/40644(2002)233, 2004.

Marchandise, A. and Viel, C.: Using the Meteo-France Safran-IsbaModcou data for operational flood warning and forecasting, La Houille Blanche, 6, 35-41, 2009(in French).

Marchi, L., Borga, M., Preciso, E., and Gaume, E.: Characterization of selected extreme flash floods in Europe and implications for flood risk management, J. Hydrol., 394, 118-133, 2010.

Montesarchio, V., Lombardo, F., and Napolitano, F.: Rainfall thresholds and flood warning: an operative case study, Nat. Hazards Earth Syst. Sci., 9, 135-144, doi:10.5194/nhess-9-1352009, 2009.

Mishra, S. K. and Singh, V. P.: Soil conservation service curve number (SCS-CN) methodology, Kluwer, Dordrecht, The Netherlands, ISBN 1-4020-1132-6, 2003.

Moulin, L., Gaume, E., and Obled, C.: Uncertainties on mean areal precipitation: assessment and impact on streamflow simulations, Hydrol. Earth Syst. Sci., 13, 99-114, doi:10.5194/hess-13-992009, 2009.

Moussa, R., Chahinian, N., and Bocquillon, C.: Distributed hydrological modelling of a Mediterranean mountainous catchment - Model construction and multi-site validation, J. Hydrol., 337, 35-51, 2007.

Nash, J. E. and Sutcliffe, J. V.: River flow forecasting through conceptual models part I: A discussion of principles, J. Hydrol., 10(3), 282-290, 1970.

Norbiato, D., Borga, M., Degli Esposti, S., Gaume, E., and Anquetin, S.: Flash flood warning based on rainfall thresholds and soil moisture conditions: an assessment for gauged and ungauged basins, J. Hydrol., 362, 274-290, 2008.

Paris Anguela, T., Zribi, M., Hasenauer, S., Habets, F., and Loumagne, C.: Analysis of surface and root-zone soil moisture dynamics with ERS scatterometer and the hydrometeorological model SAFRAN-ISBA-MODCOU at Grand Morin watershed (France), Hydrol. Earth Syst. Sci., 12, 1415-1424, doi:10.5194/hess-12-1415-2008, 2008.

Quintana Seguí, P., Martin, E., Habets, F., and Noilhan, J.: Improvement, calibration and validation of a distributed hydrological model over France, Hydrol. Earth Syst. Sci., 13, 163-181, doi:10.5194/hess-13-163-2009, 2009.

Rao, S. S.: Optimization: theory and applications, John Wiley and Sons Ltd., New Delhi, Inda, 1979.

Reed, S., Schaake, J., and Zhang, Z.: A distributed hydrologic model and threshold frequency-based method for flash flood forecasting at ungauged locations, J. Hydrol., 337(3-4), 402420, 2007.

Saulnier, G-M. and Le Lay, M.: Sensitivity of flash-flood simulations on the volume, the intensity, and the localization of rainfall in the Cevennes-Vivarais region, Water Resour. Res., 45, doi:10.1029/2008WR006906, 2009(France).

Sangati, M. and Borga, M.: Influence of rainfall spatial resolution on flash flood modelling, Nat. Hazards Earth Syst. Sci., 9, 575584, doi:10.5194/nhess-9-575-2009, 2009.

Segond, M.-L., Wheater, H.S., Onof, C.: The significance of spatial rainfall representation for flood runoff estimation: A numerical evaluation based on the Lee catchment, UK. J. Hydrol. 347, 116131, 2007.

Steenhuis, T. S., Winchell, M., Rossing, J., Zollweg, J. A., and Walter, M. F.: SCS Runoff equation revisited for variable-source runoff areas, J. Irrig. Drain. E-ASCE, 121, 234-238, 1995.

Tramblay, Y., Bouvier, C., Martin, C., Didon-Lescot, J.-F., Todorovik, D., and Domergue, J.-M.: Assessment of initial soil moisture conditions for event-based rainfall-runoff modeling, J. Hydrol., 387, 176-187, 2010.

Wagener, T., Gupta, H., Yatheendradas, S., Goodrich, D., Unkrich, C., and Shaffner, M.: Understanding sources of uncertainty in flash-flood forecasting for semi-arid regions, Proceedings of Symposium HS2004 at IUGG2007, Perugia, July 2007. 
IAHS Publ. 313, 204-212, 2007.

Yates, D. N., Warner, T. T., and Leavesley, G. H.: Prediction of a flash flood in complex terrain, Part II: a comparison of flood discharge simulations using rainfall input from radar, a dynamic model, and an automated algorithmic system, J. Appl. Meteorol., $39(6), 815-825,2000$. 